\title{
Pengelolaan Wisata Air Berwawasan Kesehatan Pemetaan Kasus Leptospirosis Faktor
} Perilaku dan Lingkungan

Hendra Rohman ${ }^{1}$, Amin Kiswantoro $^{2}$, Dinda Adelia ${ }^{3}$

${ }^{13}$ Politeknik Kesehatan Bhakti Setya Indonesia, Yogyakarta, Indonesia, hendrarohman@mail.ugm.ac.id

${ }^{2}$ Sekolah Tinggi Pariwisata Ambarrukmo, Yogyakarta, Indonesia, aminkiswantoro@gmail.com

Histori Artikel

Submitted:

1 Februari 2020

Reviewed:

1 Maret 2020

Accepted:

25 Agustus 2020

Published:

15 November 2020

\section{ABSTRAK}

Perilaku masyarakat dan kondisi lingkungan sangat potensial terhadap terjadinya kasus leptospirosis. Sumber penularan utama diduga kuat berada di sekitar lingkungan pemukiman yang terdapat genangan air dan keberadaan tikus. Tujuannya mengidentifikasi faktor kasus leptospirosis untuk pemberdayaan pengelolaan wisata air berwawasan kesehatan. Metode Deskriptif dengan rancangan cross sectional. Hasil menunjukan bahwa masyarakat mandi dan mencuci baju di sumber air sekitar wisata air. Air yang tertelan saat berenang atau merendam tubuh telah tercemar bakteri. Pengelola wisata air melakukan upaya meminimalisir tempat berkembang biak tikus. Kesimpulan: Pengelolaan berwawasan kesehatan dapat mengembangkan potensi dan daya tarik wisatawan. Adanya riwayat berwisata air dapat meningkatkan resiko kejadian leptospirosis.

Kata Kunci: Leptospirosis, tikus, wisata air

MANAGEMENT OF HEALTH ORIENTED WATER TOURISM MAPPING OF LEPTOSPIROSIS CASES BEHAVIORAL AND ENVIRONMENTAL FACTORS

\section{ABSTRACT}

Community behavior and environmental conditions are very potential for leptospirosis cases. The main source of transmission is strongly suspected to be in the vicinity of residential neighborhoods that have standing water and the presence of rats. The aims to identify leptospirosis cases, behavioral and environmental factors for empowering the management of health oriented water tourism. Method: Descriptive with cross sectional design. Results: People bathing and washing clothes at water sources around the water attractions. Water swallowed while swimming or submerging the body has been contaminated with bacteria. Water tourism managers make efforts to minimize the breeding grounds of rats. Conclusion: Health oriented management can develop the potential and attractiveness of tourists. A history of water travel can increase the risk of leptospirosis.

Keywords: Leptospirosis, rats, water tourism 


\section{PENDAHULUAN}

Banyak dijumpai mata air di Kabupaten Klaten, terutama daerah yang berada di kaki Gunung Merapi. Fenomena ini terjadi karena daerah tersebut terletak pada pada sabuk mata air (spring belt) dari Gunung Merapi. Kategori tipe curah hujan agak basah. Kebersihan lingkungan objek wisata di salah satu umbul sudah cukup bersih. Secara fisik maupun kimia, air yang berasal dari mata air umbul memenuhi batas syarat air minum. Objek wisata air umbul perlu dilakukan usaha-usaha pengembangan (Marjoko, 2010). Pengelola obyek wisata terus berinovasi agar selalu memiliki daya tarik yang bisa membuat wisatawan datang kembali ke obyek wisata umbul (Dholym, 2018).

Peningkatan signifikan terjadi di Jawa Tengah yaitu 164 kasus pada tahun 2016 menjadi 316 kasus pada tahun 2017. Kasus dan kematian akibat leptospirosis tertinggi tahun 2017 terjadi di Jawa Tengah. Terdapat enam Kabupaten/Kota yang merupakan daerah dengan masalah leptospirosis, yaitu Kota Semarang, Kabupaten Semarang, Demak, Klaten, Pati dan Purworejo. Kabupaten Klaten berada pada urutan ketiga yang memiliki masalah leptospirosis setelah Kota Semarang dan Demak.

Data Dinas Kesehatan Kabupaten Klaten, menunjukkan bahwa pada tahun 2015 ditemukan 26 kasus, tahun 2016 ditemukan 39 kasus, 2017 ditemukan sebanyak 41 kasus, dan pada tahun 2018 ditemukan 68 kasus leptospirosis. Hasil investigasi kejadian luar biasa (KLB) di Kabupaten Klaten menunjukkan bahwa penyebaran kasus leptospirosis hampir terdapat di semua kecamatan. Kondisi dan perilaku masyarakat sangat potensial terjadinya endemisitas leptospirosis. Sumber penularan utama diduga kuat berada di sekitar lingkungan pemukiman seperti genangan air sekitar rumah, keberadaan tikus di dalam maupun sekitar rumah dan faktor risiko lainnya, seperti pekerjaan, pengetahuan, perilaku hidup bersih dan sehat (PHBS), wisata air, dan daerah pertanian (Dinas Kesehatan Klaten, 2016). Penelitian ini mengidentifikasi clustering kasus leptospirosis di wilayah Kabupaten Klaten, faktor perilaku masyarakat, faktor lingkungan dan pengelolaan wisata air di wilayah tersebut untuk pemberdayaan pengelolaan wisata air berwawasan kesehatan.

\section{LITERATUR REVIEW}

Wisata air merupakan kegiatan bepergian dengan tujuan pemandangan alam maupun buatan berupa kawasan perairan, menikmati pemandangan kawasan perairan, penggunaan fasilitas wisata yang mendukung kegiatan wisata air, hiburan menikmati pemandangan atau melakukan kegiatan atraksi wisata air (Yuliasri, 2005).

Pemetaan merupakan suatu gambaran dari unsur alam atau buatan manusia, yang berada di atas maupun di bawah permukaan bumi yang digambarkan pada saat bidang datar dengan skala tertentu (Peraturan Pemerintah Republik Indonesia, 2013).

Leptospirosis merupakan zoonosis bakteri yang paling umum, keberadaan faktor lingkungan dan ekologis berpengaruh terhadap penularan, diantaranya iklim, banjir, penggunaan lahan, urbanisasi, sanitasi buruk (permukiman kumuh perkotaan) (Lau et al., 2012).

Reservoir adalah hewan-hewan yang menjadi sumber penularan leptospirosis adalah rodent (tikus), babi, sapi, kambing, domba, kuda, anjing, kucing, serangga, burung, insektivora (landak, kelelawar, tupai), sedangkan rubah dapat sebagai karier dari leptospira (Departemen Kesehatan RI, 2008).

Cara penularan yaitu manusia terinfeksi leptospira melalui kontak dengan air, tanah (lumpur), tanaman yang telah dikotori oleh air seni dan hewan-hewan penderita leptospirosis (Departemen Kesehatan RI, 2008). Bakteri leptospira masuk ke tubuh manusia dapat melalui luka atau lecet pada kulit, melalui selaput lendir mulut, hidung dan mata, darah, cairan ketuban, vagina, jaringan, tanah, vegetasi dan air yang terkontaminasi dengan urin hewan yang 
terinfeksi (World Health Organization, 2014).

Hubungan riwayat wisata air dengan kejadian leptospirosis, yaitu kegiatan yang sering menimbulkan angka kejadian luar biasa (KLB) leptospirosis disuatu daerah adalah kegiatan sosial dan rekreasi, yang mana mendorong manusia untuk kontak langsung dengan lingkungan (khususnya air dan tanah) yang telah terkontaminasi bakteri leptospirais sehingga meningkatkan resiko untuk terinfeksi. Hubungan kondisi lingkungan pemukiman dengan kajadian leptospirosis, yaitu kehadiran sampah atau limbah memicu proliferasi tikus dan karenanya dapat memicu risiko leptospirosis. Sampah juga dapat memblokir sistem drainase dan memperburuk risiko banjir.

\section{METODE}

Jenis penelitian deskriptif dengan rancangan cross sectional. Populasi adalah semua penderita leptospirosis yang bertempat tinggal di Kabupaten Klaten. Data dari Dinas Kesehatan Kabupaten Klaten pada tahun 2018 yaitu 113 orang. Pengumpulan data primer melalui observasi langsung ke rumah responden dengan menggunakan format ceklist dan dilakukan wawancara. Instrumen aplikasi ArcMap 10.3 digunakan dalam pengolahan data menjadi peta, lembar observasi, dan GPS Essential.

\section{HASIL DAN PEMBAHASAN}

\section{Data Demografi Kasus Leptospirosis}

\section{Usia}

Kejadian leptospirosis di Kabupaten Klaten banyak terjadi pada usia 20-49 tahun (39\%), diikuti usia 50-59 tahun (37\%), dan paling banyak ditemukan di Kecamatan Wedi dan Jogonalan. Pada usia tersebut, sangat rentan tertular penyakit leptospirosis karena aktifitas pekerjaan yang dilakukan warga sebagai petani memungkinkan tertularnya bakteri leptospira.
Kejadian leptospirosis tidak terjadi spesifik pada umur tertentu, namun semua umur, dari balita hingga lansia. Hasil penelitian menunjukkan bahwa sebagian penderita berumur 15-19 (4 orang), 20-49 (44 orang), 50-59 (43 orang) dan 60-69 (19 orang). Semua umur dapat terserang leptospirosis karena mempunyai potensi keterpaparan dan pengalaman terpapar yang sama.

Kasus dominan terjadi pada usia produktif umur 35 - 39 tahun. Pada faktor jenis kelamin, laki-laki lebih dominan (Rejeki et al., 2015). Lebih dari separuh responden berjenis kelamin laki-laki dengan rata-rata umur 44 tahun. Pekerjaan berisiko responden adalah sebagai petani (Rahayu et al., 2017). Kasus leptospirosis sebagian besar terjadi pada orang dewasa dengan kelompok umur 26-45 tahun $(38,3 \%)$, berjenis kelamin lakilaki $(70 \%)$, dan pekerjaan sebagai petani (44,7\%) (Nuraini et al., 2017).

\section{Jenis Kelamin}

Hasil penelitian ini menunjukkan bahwa kejadian leptospirosis banyak terjadi pada laki-laki 88 orang $(78 \%)$ sedangkan perempuan 25 orang (22\%). Laki-laki sangat berpotensi terjadinya leptospirosis karena lebih sering melakukan kegiatan yang berpotensi tertular leptospirosis, dan masih kurang peduli terhadap pentingnya penggunaan alat pelindung diri saat bekerja atau melakukan aktifitas.

Sebagian besar kasus leptospirosis terjadi pada laki-laki. Pada dasarnya laki-laki dan perempuan memiliki resiko yang sama menderita leptospirosis, akan tetapi pada umumnya laki-laki cenderung kurang peduli jika mengalami luka yang bisa menjadi tempat masuknya bakteri.

\section{Peta Clustering Kasus Leptospirosis}

Berdasarkan analisis kernel density, telah terjadi clustering atau pengelompokkan kasus leptospirosis di berbagai titik wilayah Kabupaten Klaten. Terdapat dua lokasi dengan clustering terbesar yaitu clustering pertama yang berada di tiga Kecamatan (Gantiwarno, Wedi dan Jogonalan) dan clustering yang kedua berada di wilayah 
Kota Klaten (Klaten Selatan, Klaten Tengah, dan Klaten Utara).

Pengukuran buffering jarak antar rumah penderita terdapat 26 kasus $(54,2 \%)$ dengan radius kurang dari 700 meter. Terdapat hubungan signifikan antara keberadaan tikus di dalam maupun di luar rumah dengan penyakit leptospirosis (Gavinov \& Huda, 2019). Kriteria risiko rendah dan risiko tinggi terjadi leptospirosis dibuat dalam pemetaan, untuk mempermudah intervensi pengendalian leptospirosis (Mirasa, 2017).

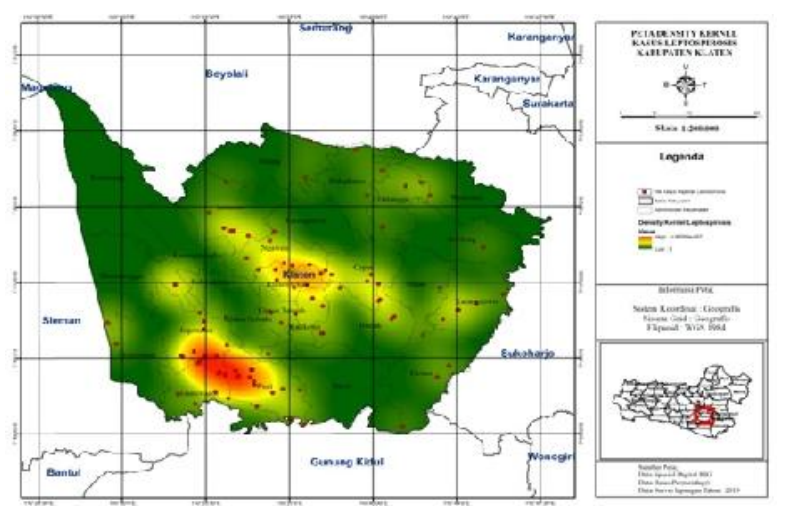

Gambar 1. Peta clustering kasus leptospirosis di Kabupaten Klaten

Sumber: Data primer, (2019)

Kasus leptospirosis tertinggi berada di Kecamatan Wedi (12\%), Gantiwarno (10\%), dan Jogonalan (8\%). Sedangkan wilayah kasus terendah terdapat di Kecamatan Juwiring (1\%), Delanggu, Bayat, Karangnongko, Manisrenggo (2\%), dan Prambanan (3\%).

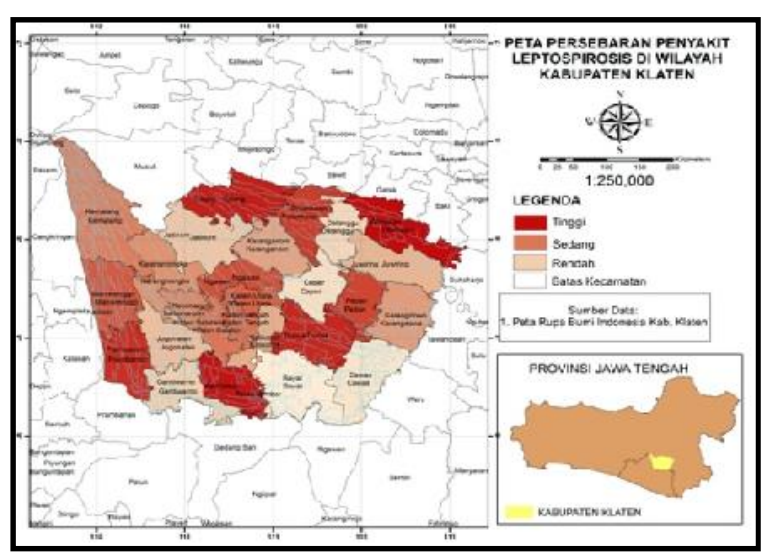

Gambar 2. Peta tingkat persebaran leptospirosis Sumber: Data primer, (2019)

\section{Faktor Perilaku dan Lingkungan}

Pada penelitian ini sebagian besar penderita leptospirosis berprofesi sebagai petani. Pada pekerjaan tersebut dapat dilakukan oleh lakilaki maupun perempuan. Oleh sebab itu, baik laki-laki maupun perempuan harus mampu mengantisipasi terjadinya leptospirosis.

Jenis pekerjaan petani yang memiliki resiko tinggi terhadap kejadian leptospirosis, banyak terjadi di wilayah Kecamatan Wedi dan Gantiwarno. Faktor yang sangat mempengaruhi yaitu kurangnya pengetahuan tentang pentingnya penggunaan alat pelindung diri (APD) pada warga di wilayah sekitar saat melakukan aktifitas di sawah. Mereka kontak langsung dengan tanah dan air yang sudah tercemar bakteri leptospirosis.

Wilayah tertinggi kasus leptospirosis tahun 2018, terdapat di daerah Kecamatan Gantiwarno (14 orang) dan Wedi (11 orang). Di daerah tersebut, banyak warga yang berternak sapi dan kambing. Keberadaan hewan ternak menjadi faktor resiko karena kandang ternak merupakan tempat persinggahan tikus, sehingga memungkinkan terjadinya kontak dengan urin tikus saat mereka membersihkan kandang ternak. Selain itu, wilayah Kecamatan Wedi dan Gantiwarno dijadikan sebagai area pertanian.

Lokasi tempat tinggal penderita, diketahui berada disekitar atau disepanjang aliran sungai. Hal ini meningkatkan untuk terjadinya penularan leptospirosis melalui air sungai, karena sebagian penduduk memiliki kebiasaan mencuci atau mandi cuci kaki (MCK) di sungai.

Leptospirosis merupakan salah satu penyakit yang berhubungan dengan pekerjaan. Pekerjaan sebagai petani berhubungan dengan kejadian leptospirosis. Pada saat menanam padi, petani banyak berdiri di dalam air, yang merupakan salah satu resiko leptospirosis. Resiko semakin diperbesar dengan kebiasaan para petani untuk tidak memakai alas kaki di sawah. Dalam hal pemakaian APD, sebagian besar petani dalam kelompok kasus memiliki pengetahuan dan sikap yang baik terhadap 
pemakaian APD. Namun, lingkungan sawah tempat mereka bekerja tidak mendukung untuk pemakaian APD karena lumpur di sawah tersebut terlalu dalam, sehingga melampaui batas sepatu boot para petani, sehingga petani lebih memilih bertelanjang kaki saat bekerja di sawah. Sebagian besar petani juga melakukan aktivitas mencari rumput di ladang, sehingga sangat berpotensi untuk menyentuh tumbuhan yang ada. Penularan leptospirosis dapat melalui tumbuhan yang terkena urine tikus infeksi bakteri leptospira.

Pengetahuan yang rendah (49\%) dan perilaku pencegahan leptospirosis yang kurang baik (80\%). Sumber informasi tentang leptospirosis lebih banyak diperoleh dari teman atau kerabat. Ada hubungan signifikan antara tingkat pengetahuan dengan perilaku pencegahan leptospirosis. Perilaku keseharian masyarakat untuk mencegah leptospirosis seperti penggunaan alat pelindung diri, penanganan bangkai, dan pengendalian tikus masih kurang baik (Pujiyanti et al., 2018). Petugas dari Dinkes harus mendidik orang untuk memakai sandal atau perlindungan kaki lainnya dengan benar, terutama bagi mereka yang bekerja di halaman dan sawah (Pratamawati et al., 2018).

Hasil penelitian ini menunjukkan bahwa sebagian besar penderita memiliki pekerjaan yang beresiko yaitu sebanyak 47 kasus memiliki pekerjaan sebagai petani dan 31 penderita sebagai pekerja kebun. Adapun penderita yang pekerjaanya sebagai potong ayam dimana kondisi tersebut sangat berportensi terjadi leptospirosis. Agar para pekerja terhindar dari penyakit leptospirosis maka pekerja harus melakukan upaya pencegahan seperti menggunakan sepatu boot dan menggunakan sarung tangan pada saat ingin kontak dengan air genangan jika memungkinkan, mencuci tangan dan kaki serta anggota tubuh lainnya dengan sabun setelah kontak dengan air atau lumpur, mengkonsumsi air bersih dan menghindari kontak dengan binatang yang bisa menularkan penyakit ini seperti tikus.
Ada perbedaan pengetahuan dan sikap petani sebelum dan sesudah diberi ceramah tentang leptospirosis. Pada pendampingan ke empat menunjukkan peningkatkan kepatuhan petani menggunakan APD yaitu $100 \%$ petani memakai sepatu boot, $85 \%$ menggunakan sarung tangan, dan 15\% menggunakannya kadang-kadang (Rejeki et al., 2015).

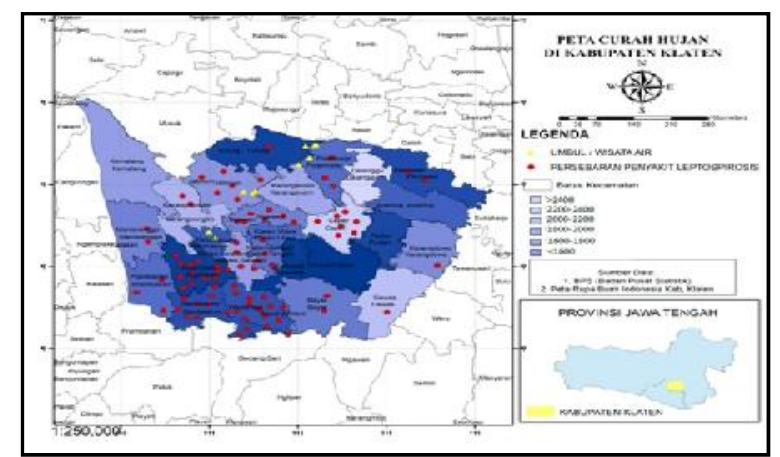

Gambar 3. Peta curah hujan Kabupaten Klaten Tahun 2018

Sumber: Data primer (2019)

Data badan pusat statistik (BPS) Kabupaten Klaten, menunjukkan bahwa ada hubungan curah hujan dengan kejadian leptospirosis. Sebagian wilayah merupakan daerah yang memiliki potensi terjadinya banjir. Kondisi ini tentunya sangat berpengaruh terhadap terjadinya kasus leptospirosis. Dalam penelitian ini hanya daerah-daerah tertentu yang berpotensi terjadinya banjir. Banjir tersebut seringkali disebabkan oleh kondisi selokan yang buruk, kondisi selokan yang tersumbat banyak sampah, membuat banyak air yang tergenang atau aliran air tidak lancar. Namun apabila aliran air lancar maka risiko banjirpun menurun. Selain itu apabila menggunakan alat pelindung diri seperti sepatu boot untuk melindungi kaki dari kontak air banjir, maka risiko penularan leptospirosis dapat dikurangi.

Daerah banjir tidak begitu berpengaruh terhadap kejadian leptospirosis di Kota Klaten. Namun, tidak menutup kemungkinan wilayah di luar daerah banjir juga pernah mengalami genangan air beberapa waktu. Kondisi tersebut dapat mengalirkan aliran sungai yang mengandung bakteri leptospira dari daerah satu ke daerah yang lain. 
Kasus terjadi pada saat curah hujan tinggi, sehingga mendukung terjadinya banjir dan genangan air (Rahayu et al., 2017). Faktor risiko lingkungan kejadian leptospirosis berupa keberadaan tanda-tanda tikus, wilayah tergenang pasca hujan, keberadaan sungai, tempat pembuangan sampah sementara, keberadaan selokan atau parit (Nurhandoko \& Siwiendrayati, 2017).

Pengendalian leptospirosis bukan hanya pada tikus tetapi juga pada lingkungan (Rejeki et al., 2015). Suatu daerah dinyatakan rawan penyebaran penyakit leptospirosis ditentukan oleh beberapa faktor, diantaranya adalah faktor lingkungan fisik, faktor demografi, dan faktor perilaku. Penduduk berjenis kelamin laki-laki, curah hujan, pekerjaan sebagai petani, dan frekuensi kejadian leptospirosis merupakan contoh objek yang memiliki ketidakpastian (Damayanti, 2019).

Masyarakat memiliki paparan yang sama terhadap air genangan sisa hujan. Semua umur sebaiknya mampu mengantisipasi agar tidak kontak dengan tikus, urin tikus atau dengan hewan lain yang dapat menularkan penyakit leptospirosis. Upaya yang bisa dilakukan yaitu dengan cara selalu melakukan pencegahan, berperilaku hidup bersih dan sehat, serta memakai alat pelindung diri ketika ingin kontak dengan hewan terinfeksi dan air genangan.

Berdasarkan data curah hujan di Kabupaten Klaten, sebaran kasus leptospirosis berada pada daerah dengan curah hujan tinggi yaitu 1.500 - $2.400 \mathrm{~mm} / \mathrm{tahun}$, ada di Kecamatan Cawas, Jogonalan, Pedan, dan Karanganom. Curah hujan yang tinggi menyebabkan terjadinya banjir yang membuat banyaknya tikus keluar dari persembunyiannya dan masuk ke lingkungan perumahan. Hal ini meningkatkan resiko terjadinya penularan leptospirosis.

Ada korelasi signifikan antara distribusi tikus positif yang dikonfirmasi leptospirosis dengan variabel ketinggian dan suhu. Namun, tidak berkorelasi dengan variabel cuaca. Semua tikus ditemukan di dataran rendah (Supranelfy et al., 2019).
Penggunaan lahan berpengaruh terhadap terjadinya leptospirosis, mayoritas kasus terjadi di area permukiman dan persawahan. Selain itu banyak terjadi di area permukiman dan kebun/tegalan. Serta banyak terjadi di area permukiman dan sekitar sungai. Lebih dari setengah kasus leptospirosis terjadi pada ketinggian 0-100 mdpl. sedangkan curah hujan berpengaruh tidak langsung dengan kejadian leptospirosis terkait adanya air permukaan yang digunakan untuk saluran irigasi (Rahmawati, 2011).

Risiko kejadian leptospirosis meningkat dengan meningkatnya riwayat luka, riwayat wisata air, konsisi lingkungan yang buruk, pekerjaan yang berisiko (tanpa alat pelindung diri), dan keberadaan tikus atau ternak (Sofiyani, et al., 2017).

Hasil penelitian ini menunjukkan wilayah yang memiliki kasus leptospirosis tertinggi berada di Kecamatan Wedi (14 kasus), Gantiwarno (11 kasus), Jogonalan (9 kasus), Tulung (5 kasus), dan Wonosari (5 kasus). Wilayah yang memiliki jumlah kasus sedang, terdapat di area perkotaan Kabupaten Klaten yaitu Klaten Selatan kasus, Klaten Tengah kasus dan Klaten Utara kasus. Sedangkan wilayah yang memiliki jumlah kasus rendah terdapat di Kecamatan Bayat dengan kasus, Ceper kasus dan Delanggu dengan 2 kasus.

Pola persebaran kasus leptospirosis berada pada posisi mengelompok mengikuti pola aliran sungai (Rejeki et al., 2015). Ada hubungan antara keberadaan genangan air, kondisi selokan, penggunaan APD saat melakukan pekerjaan berisiko, dan kebiasaan cuci tangan dan kaki dengan sabun dengan kejadian leptospirosis (Dewi \& Yudhastuti, 2019).

Keberadaan sungai di Kabupaten Klaten berpengaruh terhadap kejadian leptospirosis. Daerah pinggiran sungai di wilayah dataran rendah memiliki kerentanan tinggi terhadap kejadian banjir pada saat musim hujan. Sungai yang dekat dengan pemukiman sebagai faktor risiko karena sungai yang tergenang akibat pembuangan sampah merupakan habitat reservoir seperti tikus. 
Faktor resiko lingkungan berdasarkan lokasi (lokasi dengan kepemilikan hewan peliharaan, lokasi dengan keberadaan tikus di sekitar rumah, dan lokasi dengan tiga jenis vegetasi atau lebih), faktor resiko lingkungan berdasarkan karakteristik lingkungan (pemukiman, area luasan banjir, ketinggian tempat, curah hujan, tekstur tanah, indeks kerapatan vegetasi, temperatur, dan kelembaban), dan faktor perilaku manusia (riwayat kontak dengan hewan, penggunaan alat pelindung diri, kebiasaan mandi atau mencuci di sungai, dan riwayat kontak dengan genangan air). Pencegahan penyakit leptospirosis dapat berupa memberikan penyuluhan, melindungi para pekerja, mengenali tanah dan air yang berpotensi terkontaminasi, memberantas hewan pengerat (tikus), memisahkan hewan peliharaan yang terinfeksi, imunisasi kepada hewan ternak dan binatang peliharaan, vaksinasi, imunisasi kepada pekerja, antibiotik profilaksis, dan menutupi luka dan lecet dengan pembalut kedap air (Aziz \& Suwandi, 2019).

\section{Pemberdayaan Pengelolaan Wisata Air}

Terdapat 9 umbul atau wisata air yang menjadi faktor leptospirosis dan lokasinya tersebar di 4 kecamatan. Hampir setiap kelurahan memiliki umbul atau wisata air di Kecamatan Jatinom. Lebih dari 20 lokasi tersebar di kecataman tersebut. Beberapa umbul atau wisata air dalam kondisi tidak terawat, terutama di Kecamatan Polanharjo. Warga sekitar menggunakan air tersebut untuk mandi, mencuci dan kegiatan seharihari. Namun ada beberapa umbul atau wisata air yang terawat atau dikelola dengan baik, sehingga aman untuk dikunjungi wisatawan.

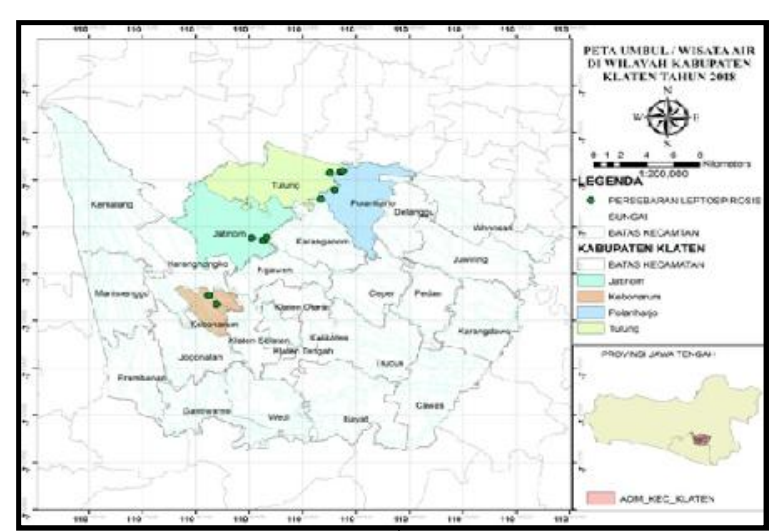

Gambar 4. Peta wisata air atau umbul di Kabupaten Klaten

Sumber: Data primer, 2019

Kecamatan Tulung terkenal dengan wisata air, hampir setiap desa terdapat wisata air, bahkan lebih dari 1 tempat wisata. Adanya riwayat berwisata air tersebut dapat meningkatkan resiko kejadian leptospirosis. Aktifitas yang mengakibatkan seseorang menelan air, yaitu berenang atau merendam tubuh ke dalam air yang tercemar bakteri leptospirosis.

Sebagian besar warga melakukan aktifitas seperti mandi dan mencuci baju di sumber air yang berada di sekitarnya merupakan salah satu faktor yang menyebabkan terjadinya wabah leptospirosis. Serta, banyaknya aliran sungai di sekitar pemukiman yang berdekatan dengan tempat tinggal penderita, kebiasaan warga sekitar melakukan aktifitas mandi, mencuci baju serta buang air besar $(B A B)$ di sungai.

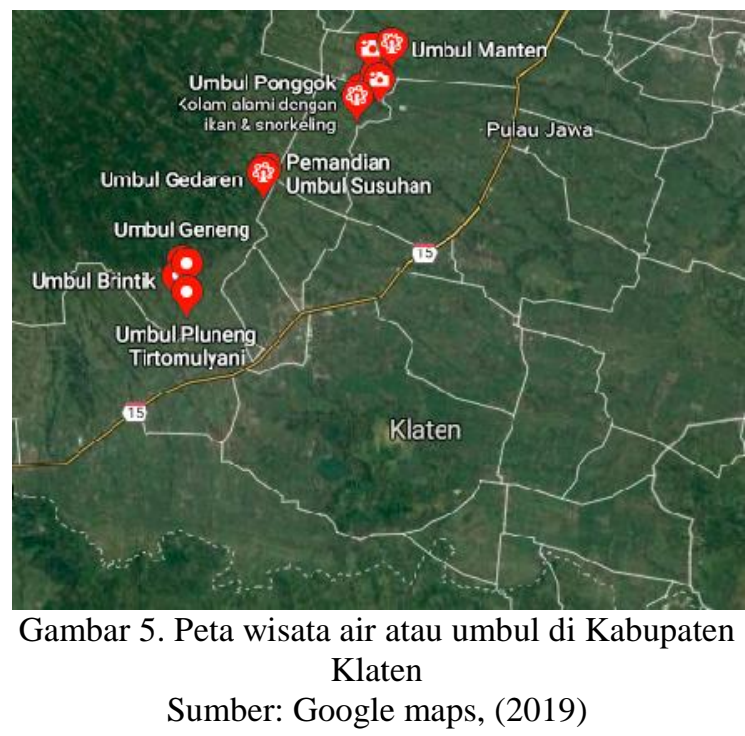


Secara geografis, di Kabupaten Klaten terdapat beberapa kecamatan yang memanfaatkan sumber mata air sebagai obyek wisata yang memiliki potensi berbedabeda.

Masyarakat perlu memperhatikan kondisi obyek wisata umbul, yaitu kebersihan obyek wisata, sehingga membuat daya tarik pendukung agar dapat menarik minat wisatawan untuk berkunjung (Jannah, 2018). Keterlibatan masyarakat dalam melaksanakan strategi dan arah kebijakan diperlukan untuk memperbaiki dan meningkatkan faktor pendukung sektor wisata (Mulyana et al., 2019).

Lingkungan merupakan salah satu faktor yang berpengaruh terhadap derjat kesehatan manusia dan masyarakat. Kepedulian masyarakat terhadap kebersihan dan kesehatan lingkungan dipengaruhi oleh empat faktor yaitu: yuridis, faktor sarana, faktor keteladanan dan faktor media informasi (Azkha, 2007).

\section{SIMPULAN}

Pengelolaan wisata air berwawasan kesehatan dapat mengembangkan potensi dan daya tarik wisatawan. Pemantauan perlu dilakukan di wilayah resiko kasus leptospirosis dan menggalakkan pencegahan melalui gerakan kebersihan lingkungan, pengendalian tikus, serta terintergrasi dengan program lintas sektoral.

Wilayah tertinggi kasus terdapat di Kecamatan Jogonalan dan Wedi. Terdapat dua lokasi dengan clusetring terbesar yaitu clusetring pertama berada di tiga Kecamatan (Gantiwarno, Jogonalan, Wedi) dan clusetring kedua yaitu di Kota Klaten (Klaten Utara, Klaten Selatan dan Klaten Tengah).

\section{REFERENSI}

Aziz, T., \& Suwandi, J. F. (2019).

Leptospirosis: Intervensi Faktor Resiko Penularan. Medical Journal of Lampung University, 8(1), 232-236. Retrieved from http://juke.kedokteran.unila.ac.id/index. php/majority/article/view/2325/2292

Azkha, N. (2007). Pembangunan Pariwisata Berwawasan Kesehatan di Sumatera Barat. Jurnal Kesehatan Masyarakat, II(1), 136-139.

Damayanti, A. (2019). Penentuan Tingkat Kerawanan Penyebaran Leptospirosis Menggunakan Inferensi Fuzzy Tsukamoto. Jurnal Sistem Komputer Dan Informatika (JSON), 1(1), 52. https://doi.org/10.30865/json.v1i1.1388

Departemen Kesehatan RI. (2008). Pedoman Diagnosa dan Penatalaksanaan Kasus Penanggulangan Leptospirosis di Indonesia. Jakarta: Direktorat Jendral Pengendalian Penyakit dan Penyehatan Lingkungan. Jakarta.

Dewi, H. C., \& Yudhastuti, R. (2019). Faktor Risiko Kejadian Leptospirosis Di Wilayah Kabupaten Gresik (Tahun 2017-2018). Jurnal Keperawatan Muhammadiyah, 4(1), 104-107.

Dholym, S. F. (2018). Analisis Faktor-Faktor yang Mempengaruhi Jumlah Pengunjung Obyek Wisata Umbul Ponggok, Desa Ponggok, Polanharjo, Klaten. Universitas Islam Indonesia.

Dinas Kesehatan Klaten. (2016). Profil Kesehatan Kabupaten Klaten 2016 (2016th ed.). Klaten, Jawa Tengah.

Gavinov, I. T., \& Huda, S. (2019). Penerapan Sistem Informasi Geografis Faktor Risiko Penyakit Leptospirosis. Jurnal Ilmiah Ilmu Kesehatan: Wawasan Kesehatan, 5(1), 170-174. https://doi.org/2598-4004

Jannah, M. (2018). Analisis Potensi Obyek Wisata Umbul di Kabupaten Klaten Jawa Tengah. Universitas Muhammadiyah Surakarta. 
Lau, C. L., Clements, A. C. A., Skelly, C., Dobson, A. J., Smythe, L. D., \& Weinstein, P. (2012). Leptospirosis in American Samoa - Estimating and Mapping Risk Using Environmental Data, 6(5). https://doi.org/10.1371/journal.pntd.000 1669

Marjoko. (2010). Analisis Potensi Dan Pengembangan Objek Wisata Air Umbul Ingas Di Kecamatan Tulung Kabupaten Klaten. Universitas Sebelas Maret Surakarta. https://doi.org/10.1558/jsrnc.v4il.24

Mirasa, Y. A. (2017). Pengembangan Model Kerawanan Daerah Sebagai Indikator Kewaspadaan Dini Leptospirosis Di Dataran Tinggi. Universitas Airlangga.

Mulyana, Y., Huraerah, A., Martiawan, R., Studi, P., Adminstrasi, I., Bandung, U. P., ... Bandung, U. P. (2019). Kebijakan Pengembangan Destinasi Pariwisata Cianjur Selatan Di Kabupaten Cianjur Jawa Barat. Jurnal Ilmu Sosial Dan Ilmu Politik, 9(1), 490-511. https://doi.org/2579-3098

Nuraini, S., Saraswati, L. D., Adi, M. S., \& Susanto, H. S. (2017). Gambaran Epidemiologi Kasus Leptospirosis Di Kabupaten Boyolali, Provinsi Jawa Tengah. Jurnal Kesehatan Masyarakat (e-Journal), 5(1), 226-234.

Nurhandoko, F., \& Siwiendrayati, A. (2017). Zona kerentanan kejadian leptospirosis ditinjau dari sisi lingkungan. Higeia Journal of Public Health Research and Development, 1(3), 140-150.

Peraturan Pemerintah Republik Indonesia. (2013). Peraturan Pemerintah Republik Indonesia Nomor 8 2013, Ketelitian Peta Rencana Tata Ruang.

Pratamawati, D. A., Ristiyanto, R., Handayani, F. D., \& Kinansi, R. R.
(2018). Faktor Risiko Perilaku Masyarakat Pada Kejadian Luar Biasa Leptospirosis Di Kabupaten Kebumen Tahun 2017. Vektora: Jurnal Vektor Dan Reservoir Penyakit, 10(2).

Pujiyanti, A., Negari, K. S., \& Trapsilowati, W. (2018). Hubungan Pengetahuan dengan Perilaku Pencegahan Leptospirosis Paska Peningkatan Kasus di Kabupaten Tangerang. Jurnal Litbang Pengendalian Penyakit Bersumber Binatang Banjarnegara, 14(1).

https://doi.org/10.22435/blb.v14i1.5942. 13-22

Rahayu, S., Sakundarno, M., \& Dian, L. (2017). Pemetaan Faktor Risiko Lingkungan Leptospirosis Dan Penentuan Zona Tingkat Kerawanan Leptospirosis Di Kabupaten Demak Menggunakan Remote Sensing Image. Jurnal Kesehatan Masyarakat (eJournal), 5(1), 218-225.

Rahmawati. (2011). Pola Sebaran Leptospirosis Di Daerah Istimewa Yogyakarta. Balai Penelitian Dan Pengembangan Pengendalian Penyakit Bersumber Binatang (P2B2) Banjarnegara.

Rejeki, D. S. S., Nurlaela, S., \& Octaviana, D. (2015). Pendidikan Kesehatan Dan Penerapan Alat Pelindung Diri Dalam Upaya Pencegahan Leptospirosis Di Desa Selandaka, Kecamatan Sumpiuh Kabupaten Banyumas. Jurnal Kesmasindo, 7(2), 118-131.

Sofiyani, M., Dharmawan, R., \& Murti, B. (2017). Risk Factors of Leptospirosis in Klaten, Central Java. Journal of Epidemiology and Public Health, 03(01), 11-24.

https://doi.org/10.26911/jepublichealth. 2018.03.01.02

Supranelfy, Y., S, N. H., \& Oktarina, R. 
(2019). Analisis Faktor Lingkungan Terhadap Distribusi Jenis Tikus Yang Terkonfirmasi Sebagai Reservoir Leptospirosis Di Tiga Kabupaten Di Provinsi Sumatera Selatan. Vektora: Jurnal Vektor Dan Reservoir Penyakit, 11(1).

World Health Organization. (2014). Leptospirosis. Geneva.

Yuliasri, A. (2005). Prioritas Pengembangan Obyek-Obyek Wisata Air Di Kawasan Rawa Pening Kabupaten Semarang. Universitas Diponegoro.

\section{BIODATA PENULIS}

Hendra Rohman, merupakan dosen tetap di Politeknik Kesehatan Bhakti Setya Indoensia Yogyakarta, bidang kajian rekam medis dan informasi kesehatan.

Id Scholar:

https://scholar.google.co.id/citations?user $=\mathrm{C}$ HOrn2kAAAAJ\&hl=id

Amin Kiswantoro, merupakan dosen tetap di Sekolah Tinggi Pariwisata Ambarrukmo Yogyakarta, bidang kajian pariwisata.

Id Scholar:

https://scholar.google.com/citations?user $=\mathrm{H}$ GhLTvQAAAAJ\&hl=en

Dinda Adelia, merupakan alumni di Politeknik Kesehatan Bhakti Setya Indoensia Yogyakarta, bidang kajian rekam medis dan informasi kesehatan. 